\title{
Proposed Changes to Social Security: An Analysis
}

Robert E. Pritchard, (Email: Pritchard@ rowan.edu), Rowan University

Gregory C. Potter, Rowan University

\begin{abstract}
Some 48 million Americans are expected to collect around $\$ 518$ billion in Social Security benefits during 2005. Of these, about 70 percent are retired workers. The ratio of workers covered by Social Security to retirees is approximately three to one but will decrease to about two to one in the next generation. Furthermore, at present, there are significantly more Social Security taxes collected than benefits paid; the excess is spent to help fund other government programs. With the Baby Boomers starting to collect benefits in 2008 and large federal deficits already threatening to push interest rates higher, providing for future Social Security funding is being addressed. This paper explores existing and future demands expected to be placed on Social Security and possible changes that may be implemented to ensure its long-term viability.
\end{abstract}

\section{INTRODUCTION}

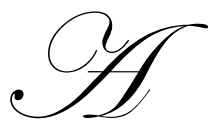

t present, about 12.6 percent of the U.S. population (36.3 million people) is 65 years or older. This cohort is expected to increase to 13.2 percent by 2020 and 20.3 percent ( 86.7 million people) by 2050. In 1935 (when Social Security began), there were 42 covered workers for each Social Security beneficiary, in 1950 there were 16; now there are three, and within about a generation there will be only two. Therefore, in another generation, on average, two workers will have to support not only themselves and their children, but also make a contribution toward the support of other non-working adults, as well as supporting one retiree.

There are no free lunches: those who work support themselves as well as everyone who does not work! As a practical matter, with the relative number of retirees increasing, the burden can be met only if 1) workers' taxes (i) are increased, 2) benefits paid to retirees are decreased, 3) the Social Security system is modified in some manner to generate added funds, and/or 4) foreigners contribute to the support of Americans (as they have been for many years, accepting IOUs in return for real goods and services).

Under current law, every year workers must contribute $12.4 \%$ of their earnings (up to a maximum earnings level of $\$ 90,000$ for 2005). For employees, the contribution consists of $6.2 \%$ deducted from workers salaries plus an additional $6.2 \%$ employer contribution. The fact that employers pay $6.2 \%$ does not mean that the cost is not borne by the employee; it is. The $6.2 \%$ employer contribution is a part of each employee's benefit package. Self-employed workers must pay the full $12.4 \%$.

The "Full Retirement Age" (also referred to as "normal retirement age") is the age necessary to receive full Social Security benefits. In 1935 the "Full Retirement Age" was set at 65. At that time, the average life expectancy at birth was 61.7 years. Now, the average life expectancy at birth exceeds 77 years. Under current law, for those born in 1937 (or earlier) the "Full Retirement Age" is still 65. The age increases in small steps to 67 for those born 1960 and thereafter.

Today (2005), about 48 million people collect approximately $\$ 518$ in Social Security benefits. This number includes 1) retired workers and their dependents, 2) survivors, and 3) disabled workers and their dependents. Over 16 percent of the population (roughly one of every six people) collects Social Security benefits. 
Until age 60, an individual's retirement benefit estimates are based on past earnings and future earnings projections as well as changes from year-to-year in the National Average Wage Index (NAWI). This Index is also used to establish the amount of earned income subject to Social Security tax ( $\$ 87,900$ for 2004 and $\$ 90,000$ for 2005). The Consumer Price Index (CPI) is used to determine the annual cost of living increases received by Social Security recipients. It should be noted that the NAWI generally increases at a greater rate than the CPI. That is, average wages usually increase more rapidly than inflation - frequently by about $1 \%$ each year.

At present, when a person reaches "Full Retirement Age," he/she may collect Full Retirement benefits and have unlimited earned income. For example, a person born in 1941 reaches "Full Retirement Age" at 65 years and eight months. So, when the person born in 1941 reaches 65 years and eight months, she/he may earn any amount and still collect full Social Security benefits. Under prior law, a person had to be age 70 to have unlimited earned income and still collect full Social Security benefits. Allowing a person to collect full benefits after reaching Full Retirement Age is designed to provide an incentive to keep people working rather than retiring.

Under current law, Social Security tax revenues exceed the total of Social Security benefits paid plus administrative costs and are expected to continue to do so until about 2018. The excess of revenues over benefits and costs are spent on other government programs. The amount of the excess, however, is credited to the Federal Old-Age and Survivors Trust Fund and the Federal Disability Insurance Trust Fund (OASDI). The assets in these "trust funds" consist of U.S. Government bonds (IOUs). The government is (and for many years has been) borrowing from the Trust Funds to pay "On Budget" government costs (e.g., farm subsidies, defense, education, etc.). Thus, the trust funds are really "accounting devices" consisting of "paper wealth." For record keeping purposes, the Trust Funds currently consist of about $\$ 1.5$ trillion in government IOUs.

\section{SOCIAL SECURITY IS HEADING FOR TROUBLED TIMES}

If Social Security is expected to generate more revenue than it pays in benefits and operating costs until 2018, and $\$ 1.5$ trillion has been credited to the Trust Funds, why all the concern? Consider the following.

First, at present, even using the excess Social Security revenues to pay for some "On-Budget" costs, the federal deficit is very large ( $\$ 413$ billion for fiscal $2004-3.6 \%$ of Gross Domestic Product (ii). This annual deficit is expected to swell even more when the newly enacted Medicare prescription drug benefits have to be paid.

Second, under current Social Security law, the Trust Funds will be depleted in 2041 or 2042, according to estimates. Keep in mind, however, that Social Security is a pay-as-you-go system. Consequently, neither the amount of government IOUs in the Trust Funds nor the depletion of the Trust Funds is relevant. If future Social Security benefits are to be paid out of the "paper wealth" Trust Funds (iii), then 1) future workers will have to pay taxes to convert the government IOUs into dollars that can be used to pay the benefits and/or 2) the government will have to borrow more money (assuming lenders are available).

Third, Baby Boomers (the cohort born between 1946 and 1964) will start turning 62 in 2008. Concurrently, many will also start collecting Social Security payments. This will result in significant increases in the amount of Social Security benefits paid. Furthermore, when the Boomers start to retire those retiring will stop paying Social Security taxes. Consequently, there will be a loss of their Social Security contributions.

Finally, contrary to some political advertising, it needs to be noted that Social Security benefits are not guaranteed. The most fundamental challenge to the idea that Social Security benefits are guaranteed can be traced to the 1960 U.S. Supreme Court ruling in Flemming v. Nestor. Justice John Hanlan stated that Social Security "was designed to function into the indefinite future, and its specific provisions rest on predictions as to expected economic conditions, which must inevitably prove less than wholly accurate, and on judgments and preferences as to the proper allocation of the nation's resources which evolving economic and social conditions will of necessity in some cases modify." 


\section{POSSIBLE CHANGES TO SOCIAL SECURITY}

Some possible ideas for changes to Social Security are described below. They are designed both to increase Social Security revenues and/or decrease the rate of increase in benefit payments. It is likely that all or some of them will become law within the next few years.

* Increase the rate of payroll tax deductions from the present 12.4 percent (6.2 percent each from worker and employer). Even a small increase would generate an enormous amount of additional money. During 2002, for example, total Social Security taxes paid were about $\$ 677$ billion. If the total rate of payroll deductions had been 13.4 percent, this figure would have increased by about $\$ 55$ billion to approximately $\$ 732$ billion.

* Index workers' future benefits to the CPI rather than the NAWI. That is, shift benefit increases from "wage indexing" to "price indexing." As an alternative to shifting all indexing to "wage indexing," "wage indexing" might be utilized until a person reaches age 50 (instead of the current age 60) and "price indexing" after age 50. A second alternative would be to use "wage indexing" for lower-income workers and "price indexing" for higher-income workers. Since the NAWI tends to increase more rapidly than the CPI, any of these three options could become a major long-term cost saver.

* Increase the "Full Retirement Age" in steps to age 70. Then, index it to correspond with changes in life expectancies. That is, link benefits to life expectancy.

* Subject all or a greater portion of earned income (primarily wages) to Social Security tax. Currently (2005), the Social Security tax "wage cap" is $\$ 90,000$. That is, Social Security tax is paid only on the first $\$ 90,000$ of earned income. By contrast, Medicare tax is paid on all earned income. As an alternative, rather than taxing income above the "wage cap" at the current $12.4 \%$ (6.2\% each for employer and employee), earnings above the "wage cap" might be taxed at a lower rate such as $4 \%$ ( $2 \%$ each for employer and employee).

* Reduce the annual cost of living increases for those receiving Social Security benefits from the current rate (annual change in the CPI) to the CPI less one-half percent. The impact to individual Social Security recipients would be very small and the savings would be great over time. As an alternative, indexing at the CPI could be continued for lower income retirees and the CPI less one-half percent phased in for higher income retirees.

* Subject all Social Security benefits to federal income tax for higher income recipients. At present, a maximum of 85 percent is subject to tax even for retirees with high incomes.

* Phase out Social Security benefits for those recipients with very high retirement income. The higher the retiree's income, the lower her/his benefit.

* Eliminate all Social Security benefit payments for those who do not live within the United States or its territories or protectorates. During 2002 some 414,000 people who did not meet this requirement collected about $\$ 2.5$ billion in Social Security benefits (out of about $\$ 454$ billion paid).

* $\quad$ Reduce the age at which workers may collect Social Security benefits and have unlimited earned income from the current "Full Retirement Age" to a lower age (such as 65). The goal of this change would be to make it more attractive for older workers to continue working after age 65 .

There are a number of economic benefits to making it attractive for older workers to continue working. Offering an incentive for older workers to remain in the work force is a good idea from a macroeconomic viewpoint for the following reasons: 
- Those who work support themselves plus all others as well. Therefore, keeping older workers in the workforce generating output (as well as paying income and Social Security taxes) helps spread the burden of supporting retirees (as well as everyone else who does not work).

- Older people working full time usually have relatively high incomes and, therefore, often pay significant amounts of income taxes and, of course, Social Security taxes. Consequently, there may be little out-of-pocket cost to Uncle Sam to pay Social Security benefits (without any earned income limitations) starting at age 65 rather than holding off until Full Retirement Age.

- Prior to retirement, few people draw any pension or Individual Retirement Account benefits. By contrast, if they continue to work, they are likely to continue contributing to these accounts. When people continue to work (rather than retiring) they add to (rather than deplete) the stock of funds available for borrowing and investment. Therefore, the net effect of older workers remaining in the workforce is to lower the demand for funds, thereby tending to lower interest rates and buoy upward the price of stock.

- When people are working they tend to have higher incomes and often spend (or save) more than during retirement years when discretionary spending may be reduced. Any incremental spending will stimulate demand and economic growth. Any incremental savings/investment will add to the funds available for savings and investment, thereby tending to lower interest rates and buoy upward the price of stock.

If the age at which workers can have unlimited earned income remains tied to the "Full Retirement Age" (which is increasing under current law to age 67), then the incentive to continue working will be diminished over time. (How many people will want to plan to continue working full time after age 67?)

By allowing workers to have unlimited earned income at age 65 and still collect Social Security benefits, workers would know that once they reach 65 , they will, in effect, receive a significant pay raise. This could provide many with an incentive to continue working full time. Of course, their monthly Social Security checks will be somewhat smaller at age 65 than at their "Full Retirement Age."

* Require all state and local government workers to join Social Security. This would add about four million workers and increase revenues substantially. Alternatively, require only all new state and local government workers to participate in Social Security.

* Change the estate tax law so that amounts exceeding some threshold (perhaps $\$ 10,000,000$ ) would be subject to estate tax and dedicate this tax to Social Security.

* This seemingly simple idea has a significant drawback: money is fungible. Consequently, it would be very difficult to know if the estate taxes collected were actually spent on Social Security, just as it is difficult to know if gasoline taxes are all spent on roads, etc.

\footnotetext{
${ }^{\mathrm{i}}$ The reader correctly notes the lack of any mention of raising corporate or other sources of taxes. The reason for this omission is that in all economies the tax burden ultimately is born by those who work. The challenge of taxation is to create policies that will both raise sufficient funds while at the same time stimulate investment in productive resources - investment that will result in increased productivity.

${ }^{\text {ii }}$ For purposes of comparison, the deficit peaked at 6\% of GDP in 1983.

iii If the surplus Social Security revenues had been invested in real estate or corporate stock and/or bonds, for example, rather than spent for On-Budget government programs, then the real estate or stock and bonds could be sold and the proceeds used to pay Social Security benefits to future retirees.
} 